\title{
Bromatology of Tifton 85 Grass Irrigated with Two Qualities of Water and under Organic Fertilization
}

\author{
Maria Teresa Cristina Coelho do Nascimento ${ }^{1}$, Joelma Sales dos Santos ${ }^{1}$, Carlos Alberto Vieira de Azevedo ${ }^{1}$, \\ Vera Lucia Antunes de Lima ${ }^{1} \&$ Rubens Barrichello Gomes Barbosa ${ }^{1}$ \\ ${ }^{1}$ Universidade Federal de Campina Grande, Brazil \\ Correspondence: Maria Teresa Cristina Coelho Do Nascimento, Universidade Federal de Campina Grande, \\ Brazil. E-mail: teresacristina.eng@gmail.com
}

Received: August 20, 2017

Accepted: September 20, 2017 Online Published: October 15, 2017

doi:10.5539/jas.v9n11p172

URL: https://doi.org/10.5539/jas.v9n11p172

\begin{abstract}
The reuse of solid and liquid wastes has become a viable practice for the sustainability of agricultural production, because it meets the nutritional needs of crops and also allows the use of nutrients present in these residues. The objective of this work was to analyze the nutritional value of Tifton 85 irrigated with treated domestic wastewater and fertilized with nitrogen doses from poultry bed in four successive cuts, with frequency of 35 days. The experiment was set up in a protected environment, arranged in a completely randomized experimental design, in a $5 \times 2$ factorial scheme, with four replications. Five doses of nitrogen were tested through organic fertilization from avian beds $\left(0,15,30,45\right.$ and $\left.60 \mathrm{~kg} \mathrm{~N} \mathrm{ha}^{-1}\right)$ and two irrigation water qualities (treated domestic well and artesian well). After the cuts the material was dried and sent to the laboratory to determine the following parameters: crude protein (CP), neutral detergent fiber (NDF) and Tifton 85 acid detergent fiber (ADF) The highest values of crude protein were obtained using the domestic wastewater treated in the irrigation, as well as using the higher doses of nitrogen from poultry litter. Just as the NDF and ADF contents presented the best values when treated domestic wastewater and the highest nitrogen doses. Indicating that irrigation with wastewater and the use of organic fertilizer may substitute for conventional manures by promoting satisfactory levels of concentrations for fodder.
\end{abstract}

Keywords: Cynodon, grazing, wastewater, animal nutrition

\section{Introduction}

Currently, it is essential to implement the practice of reuse of organic waste to maintain and improve the sustainability of agricultural production systems, especially those wastes generated on site to be reused. According to A. F. Silva and M. C. B. C. da Silva (2016) the use of organic waste contributes to increase the fertility of cultivated areas and reduces the loss of water through evaporation and the accumulation of waste in the form of trash, where the disposal of them in inappropriate places can cause serious problems in the ecological balance, however, the benefits of this practice do not arise immediately, but in the medium and long term.

The reuse of water in irrigation is a necessary alternative, by the contribution of nutrients present in the same that provide the development of the cultures, contributing to the environmental preservation and control and efficient use of water in regions with low availability of water resources (Monteiro et al., 2014). In addition to the use of organic solid waste in replacing chemical fertilizers, which can guarantee the nutritional needs of plants without causing negative effects to the environment, however, there is little information on the amount of nutrients present in it, as well as the ideal amount to be incorporated into the soil.

Given the importance of livestock farming as one of the main economic activities of the country, the study of tropical forages is indispensable. The Tifton 85 is among the forages of the genus Cynodon well adapted to the tropical and subtropical climate and is widely used for the production of hay, for achieving high production and high nutritional value (Taffarel et al., 2014). And to achieve maximum feed yield, in addition to other factors, adequate availability of water and nutrients is indispensable. According to Neres et al. (2012) it is essential that fodder be produced through sustainable practices, reaching maximum productivity over the years without causing high damages to the environment, mainly due to the importance of maintaining this activity for the country's economy. 
Therefore, the objective of this work was to analyze the nutritional value of Tifton 85 irrigated with treated domestic wastewater and fertilized with doses of nitrogen available in poultry litter grown in a protected environment.

\section{Material and Methods}

The experiment was carried out in a protected environment, belonging to the Center for the Sustainable Development of the Semi-Arid of the Federal University of Campina Grande, Sumé Campus, PB, located at the following geographical coordinates: $7^{\circ} 40^{\prime}$ south latitude and $36^{\circ} 52^{\prime}$ west longitude and the average altitude is $518 \mathrm{~m}$. The experimental design was a completely randomized design with four replications, in a $5 \times 2$ factorial scheme, totaling 40 experimental units. Five doses of nitrogen were used in the organic fertilizer $(0 ; 15 ; 30 ; 45$ and $60 \mathrm{~kg} \mathrm{~N} \mathrm{ha}^{-1}$ ) Corresponding to $0 ; 6.20 ; 12.30 ; 18.50$ and $24.60 \mathrm{~g}$ vase $^{-1}$ of this material, and two qualities of irrigation water (treated domestic wastewater and artesian well water). The experimental units were composed of plastic glasses with a capacity of $29 \mathrm{dm}^{3}$, filled with a $4.5 \mathrm{~cm}$ layer of gravel to facilitate drainage, concluding with the soil mix and the organic fertilizer according to the treatments.

The soil used in the experiment classified as Luvissolo Crômico Órtico Típico (Embrapa, 2014), before filling the vessels, a sample of this soil was sent to the laboratory for physicochemical analysis, Table 1.

Table 1. Physical-chemical characteristics of the soil used in the experiment

\begin{tabular}{|c|c|c|c|c|c|c|c|c|c|c|c|c|c|}
\hline $\mathrm{pH}$ & $\mathrm{MO}$ & $P$ & $\mathrm{~K}$ & $\mathrm{Ca}$ & $\mathrm{Mg}$ & $\mathrm{Al}$ & $\mathrm{H}+\mathrm{Al}$ & $\mathrm{Na}$ & SB & CTC & Sand & Silt & Clay \\
\hline & $-\mathrm{g} / \mathrm{kg}-$ & ---- mg & $\mathrm{dm}^{3}----$ & --- & -- & 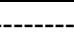 & $\mathrm{cmol}_{\mathrm{c}} / \mathrm{dr}$ & -- & -- & ---- & ---- & $-{ }_{0} \%$ & ---- \\
\hline 6.7 & 11.35 & 13.56 & 377.53 & 7.65 & 5.28 & 0.00 & 1.65 & 0.30 & 14.50 & 16.15 & 61.53 & 27.05 & 11.42 \\
\hline
\end{tabular}

Note. Held at the Federal University of Paraíba, Campus II.

The organic fertilizer used was a poultry litter from a broiler farm located in the city of Sumé, PB, the material used for the absorption of poultry waste is sugarcane bagasse. After the material was removed from the farm it was stored in sealed bags for a period of 20 days, then air dried and sieved. Before its use in the experiment, a sample of this material was submitted to chemical analysis, to determine the levels of nitrogen, phosphorus and potassium, 21.9; 5.16 and $11.88 \mathrm{~g} \mathrm{~kg}^{-1}$, respectively.

The Tifton 85 grass was cultivated in the period from June to December 2016, the seedlings came from the Fazenda Veneza do Juá located in the municipality of Sumé, PB, where the owner grows the irrigated grass to keep his flock of goats and sheep. After 15 days of incubation of the soil with the organic fertilizer, four seedlings were transplanted in each of the experimental units (vessel with volume of $29 \mathrm{dm}^{3}$ ), where each molt was composed of rooted stolons. After the transplanting, irrigations were carried out for a period of 30 days with water supply for a better stabilization of the grass. After 30 days a standardization cut was made at a height of approximately $0.10 \mathrm{~m}$ of the soil level and the use of treated domestic wastewater and well water was started according to the treatments. Four cuts of Tifton 85 grass were performed every 35 days after the standardization $\operatorname{cut}(35,70,105$ and 140 days).

Two types of water were used in the irrigation: treated domestic waste and artesian well, from the Sewage Treatment Station that uses Stabilization Ponds as a treatment system, from the city of Sumé and, of the artesian well located near the protected environment, respectively. Both irrigation waters underwent chemical analyzes prior to their use (Table 2).

Table 2. Chemical analysis of water used for irrigation

\begin{tabular}{llllllllllllll}
\hline & $\mathrm{pH}$ & $\mathrm{CE}$ & $\mathrm{Ca}$ & $\mathrm{Mg}$ & $\mathrm{Na}$ & $\mathrm{K}$ & $\mathrm{SO}_{4}^{-2}$ & $\mathrm{CO}_{3}^{-2}$ & $\mathrm{HCO}_{3}^{-}$ & $\mathrm{Cl}^{-}$ & $\mathrm{RAS}$ & PST & $\mathrm{N}$ \\
\hline \multirow{2}{*}{ Well water } & 7.63 & 1.57 & 6.65 & 7.51 & 5.89 & 0.28 & 0.34 & 0.60 & 11.80 & 11.10 & 2.21 & 1.97 & 0.0 \\
Wastewater & 8.21 & 1.84 & 3.80 & 3.65 & 11.13 & 1.13 & 0.39 & 1.40 & 12.30 & 13.70 & 5.77 & 6.76 & 60.0 \\
\hline
\end{tabular}

Note. Held at the Federal University of Campina Grande. 
Irrigation was performed daily at 9:00 am, and to quantify the volume of water to be applied to irrigation, the evaporation of the "Class A" tank installed within the protected environment. The Kp recommended by Fernandes et al. (2004) and because the Tifton 85 grass does not yet have a specific Kc for its phenological phases, was adopted a Kc (single and constant equal to 0.80) recommended by Alencar et al. (2009), established on the basis of research results and field experiments for pasture irrigation.

After Tifton 85 cuts were performed at 35, 70, 105 and 140 DAC (days after standardization cut), the pre-drying of the material of each cut was carried out in a greenhouse with forced air circulation at $65{ }^{\circ} \mathrm{C}$ for 72 hours (Gardner, 1986). After drying, the samples were ground in a Willey type, mill with a $4 \mathrm{~mm}$ diameter sieve, then packed in plastic bags pre-identified to be referred to the Laboratory of Animal Nutrition and Food Analysis of the Center of Agricultural Sciences of the Federal University of Paraíba, Areia, PB.

In these pre-dried samples the total dry mass of the forage was determined in a drying oven and sterilized at $105{ }^{\circ} \mathrm{C}$, analyzing later the bromatology of Tifton 85 , through the determination of crude protein (CP) by the Kjeldahl method, content of neutral detergent fiber (NDF) by the Van Soest method (1991) and acid detergent fiber (ADF) by the method of Goering and Van Soest (1970).

The statistical evaluation of the data was performed in the software Assistat 7.7 Beta (Silva \& Azevedo, 2016) and the data were submitted to analysis of variance, by the test F. For the comparison between averages, the Tukey test at 5\% probability was used.

\section{Results and Discussion}

It was observed that there was a significant difference as a function of the nitrogen levels in the crude protein content in the second and fourth cuts, in neutral detergent fiber and acid detergent fiber only in the third cut. As a function of irrigation water, there was a significant difference in all the cuts made in CP values, in the NDF values only in the third cut and in the second to fourth cut ADF values, Table 3. 
Table 3. Mean values of crude protein, neutral detergent fiber and Tifton 85 acid detergent fiber in four successive cuts as a function of Nitrogen doses and irrigation water quality

\begin{tabular}{|c|c|c|c|c|}
\hline \multirow{2}{*}{ Treatments } & $1^{\text {st }} \mathrm{Cut}$ & $2^{\text {nd }} \mathrm{Cut}$ & $3^{\text {rd }} \mathrm{Cut}$ & $4^{\text {th }} \mathrm{Cut}$ \\
\hline & \multicolumn{4}{|l|}{$\mathrm{CP} \%$} \\
\hline \multicolumn{5}{|l|}{ Doses of Nitrogen $\left(\mathrm{kg} \mathrm{ha}^{-1}\right)$} \\
\hline 0 & $9.12 \mathrm{a}$ & $11.13 \mathrm{ab}$ & $10.25 \mathrm{a}$ & $9.90 \mathrm{ab}$ \\
\hline 15 & $9.60 \mathrm{a}$ & $10.91 \mathrm{~b}$ & $10.31 \mathrm{a}$ & $9.22 \mathrm{~b}$ \\
\hline 30 & $9.47 \mathrm{a}$ & $11.26 \mathrm{ab}$ & $10.60 \mathrm{a}$ & $10.82 \mathrm{a}$ \\
\hline 45 & $10.15 \mathrm{a}$ & $11.39 \mathrm{ab}$ & $10.74 \mathrm{a}$ & $10.97 \mathrm{a}$ \\
\hline 60 & $10.51 \mathrm{a}$ & $11.36 \mathrm{a}$ & $10.52 \mathrm{a}$ & $10.39 \mathrm{ab}$ \\
\hline \multicolumn{5}{|l|}{ Irrigation Water } \\
\hline Treated domestic waste & $10.88 \mathrm{a}$ & $12.29 \mathrm{a}$ & $11.22 \mathrm{a}$ & $11.38 \mathrm{a}$ \\
\hline \multirow[t]{2}{*}{ Artesian well } & $8.66 \mathrm{~b}$ & $10.53 \mathrm{~b}$ & $9.75 \mathrm{~b}$ & $9.13 \mathrm{~b}$ \\
\hline & NDF\% & & & \\
\hline \multicolumn{5}{|c|}{ Doses of Nitrogen $\left(\mathrm{kg} \mathrm{ha}^{-1}\right)$} \\
\hline 0 & $71.5 \mathrm{a}$ & $74.8 \mathrm{a}$ & $75.2 \mathrm{a}$ & $72.1 \mathrm{a}$ \\
\hline 15 & $71.0 \mathrm{a}$ & $73.6 \mathrm{a}$ & $73.4 \mathrm{ab}$ & $73.8 \mathrm{a}$ \\
\hline 30 & $72.4 \mathrm{a}$ & $73.9 \mathrm{a}$ & $74.5 \mathrm{a}$ & $73.6 \mathrm{a}$ \\
\hline 45 & $71.7 \mathrm{a}$ & $74.2 \mathrm{a}$ & $73.6 \mathrm{ab}$ & $72.9 \mathrm{a}$ \\
\hline 60 & $71.5 \mathrm{a}$ & $75.3 \mathrm{a}$ & $71.2 \mathrm{~b}$ & $73.0 \mathrm{a}$ \\
\hline \multicolumn{5}{|l|}{ Irrigation Water } \\
\hline Treated domestic waste & $71.8 \mathrm{a}$ & $74.3 \mathrm{a}$ & $72.5 \mathrm{~b}$ & $72.9 \mathrm{a}$ \\
\hline \multirow[t]{2}{*}{ Artesian well } & $71.4 \mathrm{a}$ & $74.4 \mathrm{a}$ & $74.7 \mathrm{a}$ & $73.3 \mathrm{a}$ \\
\hline & $\mathrm{ADF} \%$ & & & \\
\hline \multicolumn{5}{|l|}{ Doses of Nitrogen $\left(\mathrm{kg} \mathrm{ha}^{-1}\right)$} \\
\hline 0 & 31.9 & $28.4 \mathrm{a}$ & $27.4 \mathrm{a}$ & $26.4 \mathrm{a}$ \\
\hline 15 & 31.4 & $27.8 \mathrm{a}$ & $27.0 \mathrm{ab}$ & $27.7 \mathrm{a}$ \\
\hline 30 & 30.9 & $28.2 \mathrm{a}$ & $26.9 \mathrm{ab}$ & $27.6 \mathrm{a}$ \\
\hline 45 & 31.0 & $28.9 \mathrm{a}$ & $27.1 \mathrm{ab}$ & $26.3 \mathrm{a}$ \\
\hline 60 & 29.5 & $27.1 \mathrm{a}$ & $25.7 \mathrm{~b}$ & $26.5 \mathrm{a}$ \\
\hline \multicolumn{5}{|l|}{ Irrigation Water } \\
\hline Treated domestic waste & 31.1 & $27.1 \mathrm{~b}$ & $26.1 \mathrm{~b}$ & $26.2 \mathrm{~b}$ \\
\hline Artesian well & 30.8 & $29.1 \mathrm{a}$ & $27.5 \mathrm{a}$ & $27.6 \mathrm{a}$ \\
\hline
\end{tabular}

Note. Means followed by the same letter in the column do not differ from each other by the Tukey test at $5 \%$ probability.

In relation to the nitrogen doses, the crude protein content presented higher values in the second cut, buying the other cuts. It may be related to the lower mass growth of the aerial part of the grass, because Menegatti et al. (2002) affirm that higher protein contents can be attributed to a possible effect of $\mathrm{N}$ concentration in the grass due to a lower yield of dry mass. Similar behavior was observed by Amaral (2014) which evaluated nitrogen application times for three growth periods (cuts), observed that the dry matter yield of shoot Tifton 85 was inversely proportional to the protein content observed in each cut, still according to the same author this difference happened due to the age of the plant and the climatic conditions that the grass was submitted.

In general, higher nitrogen rates (45 and $60 \mathrm{~kg} \mathrm{ha}^{-1}$ ) promoted higher levels of crude protein in Tifton 85, besides the quantities of $\mathrm{N}$ applied via irrigation water, originating from treated domestic wastewater. Indicating, therefore, that the greater the amount of nitrogen available for Tifton 85 , the higher the crude protein content of the same and, consequently, the better the quality of the forage.

In Figure 1 it can be seen that there was a reduction in the percentage of PB of Tifton 85, from the second to the fourth cut according to the application of $\mathrm{N}$ doses. As well as the results found by Amaral (2014), where the percentage of crude protein decreased from $19.9 \%$ to $15.85 \%$, from the first to the third cut. For this author the justification for this reduction may be the allocation of nutrients for the formation of new leaves, stolons, etc. 


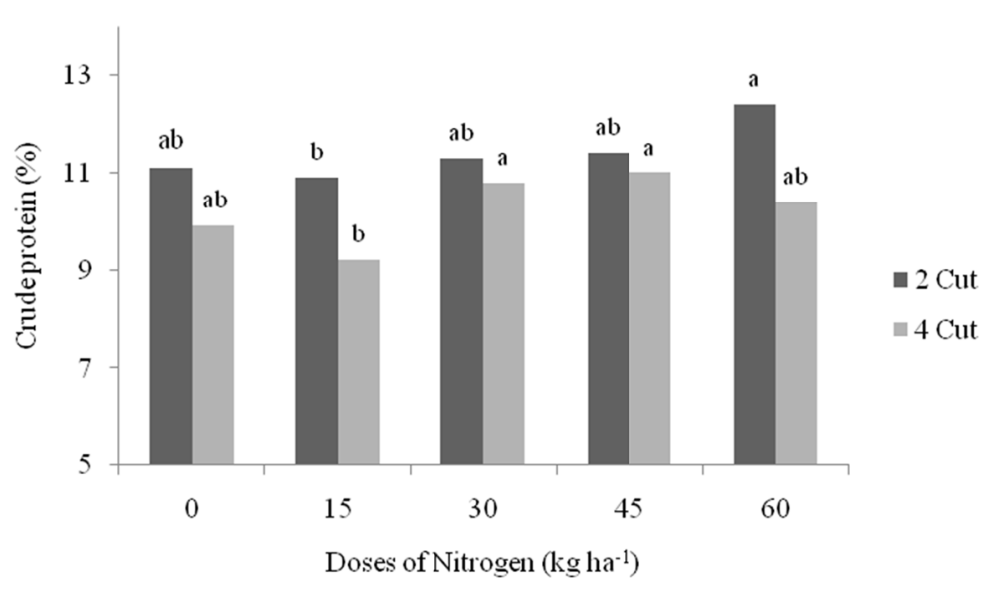

Figure 1. Crude Protein content (CP) of Tifton 85 grass as a function of Nitrogen doses $\left(\mathrm{kg} \mathrm{ha}^{-1}\right)$, in the second and fourth cuts

In Figure 2, the effect of the use of treated domestic wastewater on the crude protein content of Tifton 85, pointing out superiority of this water when compared to artesian well water in the four cuts made.

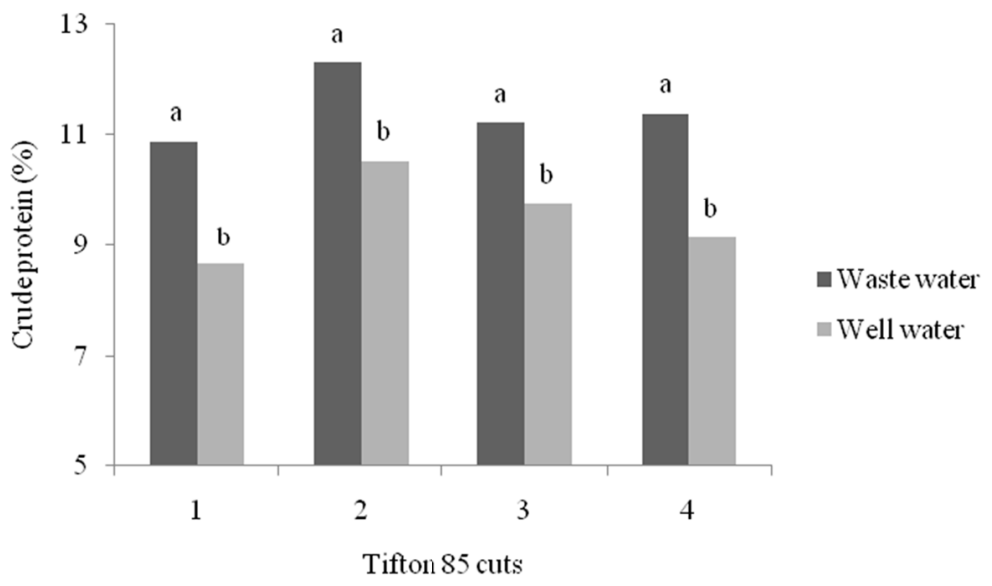

Figure 2. Crude Protein content (CP) of Tifton 85 grass as a function of the cuts for water used in irrigation, average of four cuts

It is also possible to observe that both the experimental units irrigated with waste water and those irrigated with well water, resulted in Tifton 85 with higher crude protein levels in the second cut compared to the other cuts, which may still be related to lower mass production of Tifton 85 aerial part. Costa et al. (2007) they affirm that there is an inversely proportional effect of the mass production with the nutritive value of the fodder produced.

The lowest values of crude protein obtained in this research in all the cuts were above $9 \%$, being in accordance with the recommended one to meet the animal's protein needs, because second Silva et al. (2007) protein content below $6 \%$ limits animal production, for motivating lower voluntary consumption, result of the low digestibility of the fibrous fraction.

The mean values of NDF in the first cut were lower than the means of the following cuts, both as a function of N doses and as a function of irrigation water, this difference may be related to plant age, however, the values are in agreement with those recommended for an adequate feed for the animal, with NDF contents higher than $60 \%$ that guarantee high digestibility of the fibrous fraction (Silva et al., 2007). For Balsalobre et al. (2003), the plants of the genus Cynodon are characterized by having a high proportion of NDF, when this happens the lignin content is relatively low, which gives them good quality. 
The mean NDF values found in this study ranged from 70.0 to $75.3 \%$, similar to the means found by Poczynek et al. (2016) from 68.75 to $72.27 \%$, and relatively lower than the means found by Quaresma et al. (2011) which was 79.56 to $82.99 \%$.

A negative linear effect was observed in the NDF content of Tifton 85 as a function of the nitrogen rates applied to the soil in the third cut. This effect occurred for both wastewater and well water, Figure 3.

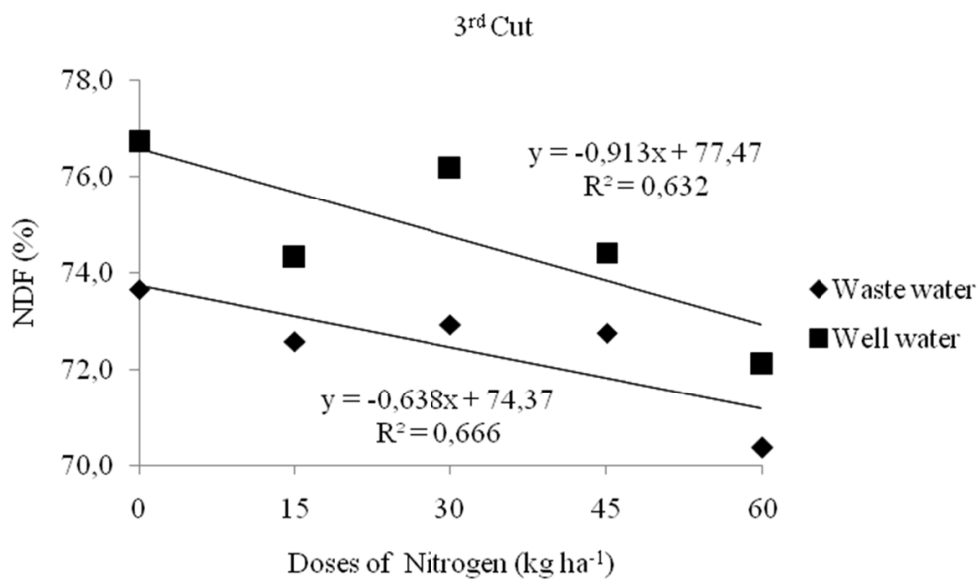

Figure 3. Neutral detergent fiber (NDF) content of Tifton 85 grass as a function of nitrogen rates for irrigation water in the third cut

Similar behavior was observed Quaresma et al. (2011), which analyzed a linear reduction of NDF as a function of nitrogen doses applied to the soil. The same was observed by Ribeiro and Pereira (2010), having averages of 82.3 and $84.2 \%$ of NDF for the second and third cuts, respectively.

The highest averages of ADF were observed in the first cut, presenting a reduction of this parameter in the other, probably due to the time required for a greater interaction of treatments.

Quaresma et al. (2011) did not observe a significant effect on the content of ADF as a function of nitrogen doses, these same authors observed a mean of $44.37 \%$ for doses from 0 to $240 \mathrm{~kg} \mathrm{ha}^{-1}$, while in this experiment the average found was $28.2 \%$ for the doses of 0 to $60 \mathrm{~kg} \mathrm{ha}^{-1}$. Santos et al. (2008) analyzing grasses of the genus Cynodon under irrigation conditions and without irrigation, also did not observe significant effects, obtaining a mean of $39.5 \%$ of ADF of Tifton 85 for both conditions.

The ADF content is related to the lignin content of the food, which defines the digestibility of the fiber, where the lower the lower the content of ADF is lignin. According to Ribeiro and Pereira (2010) the application of nitrogen increases the accumulation of fibrous tissues, such as NDF and ADF, which are inversely proportional to digestibility.

In Figure 4, it can be observed that the highest ADF means were obtained when irrigation was done with well water when compared to irrigation with wastewater, these results show that the composition of the wastewater can promote a better digestibility of this grass. According to Norton (1982) the levels of NDF and ADF are related to the maturity of the plant, because with the advancement of plant age increases the degree of lignification of tissues, which is associated with cellulose and cell wall hemicellulose, reducing the digestibility of the fiber. 


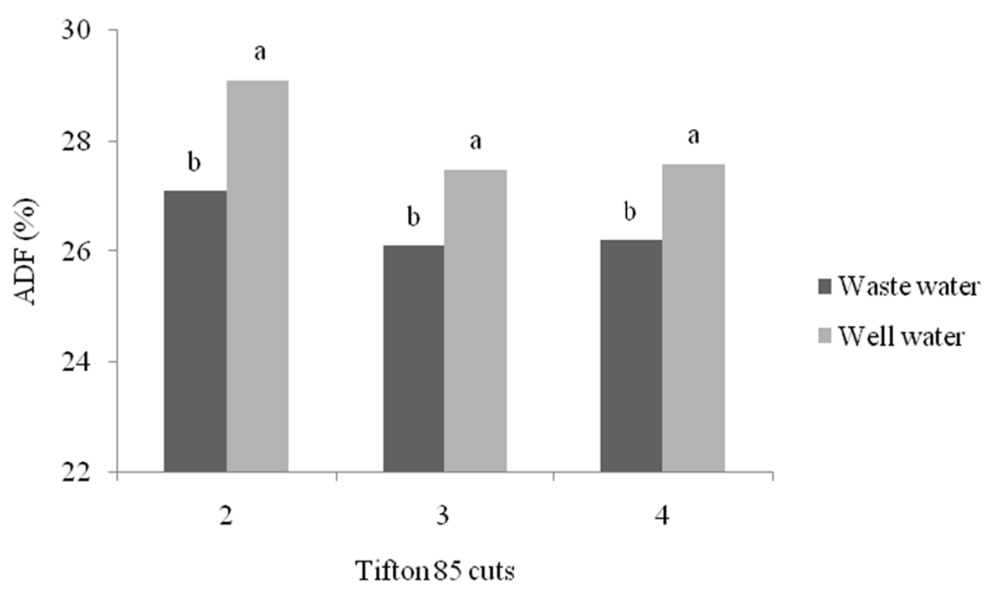

Figure 4. Tifton 85 acid detergent fiber (ADF) content as a function of cuts for water used in irrigation

There was an effect on Tifton 85 acid detergent fiber content as a function of the nitrogen doses in the third and fourth cuts, indicating the dose of $60 \mathrm{~kg} \mathrm{~N} \mathrm{ha}^{-1}$ that promoted the lowest values of ADF, suggesting, therefore, that the higher the amount of nitrogen available to the plant the lower the ADF content, Figure 5.

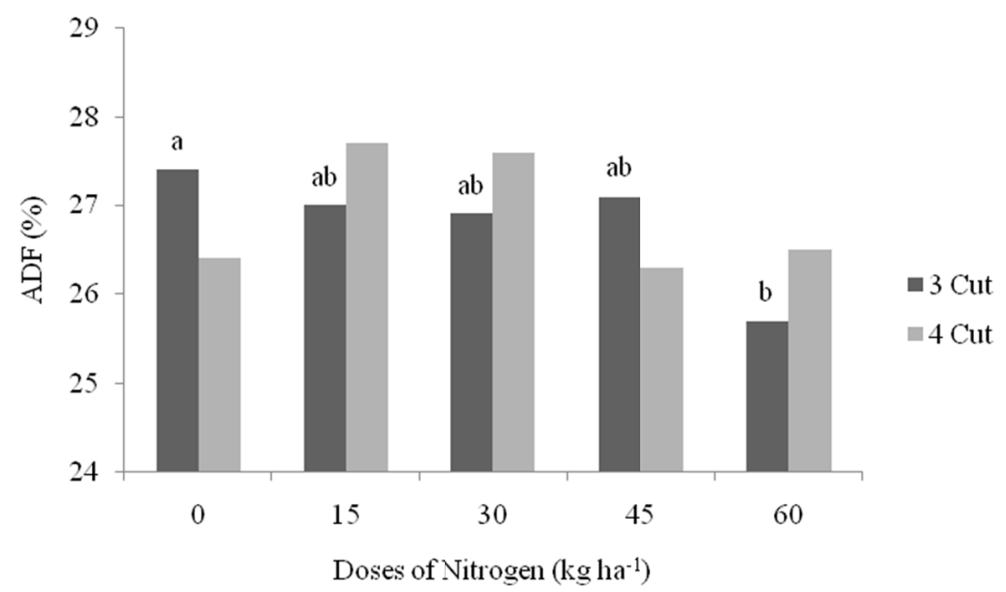

Figure 5. Tifton 85 acid detergent fiber (ADF) content as a function of the nitrogen doses in the third and fourth cuts

Silva et al. (2017) analyzing the quality of Tifton 85 under poor irrigation conditions, did not observe significant differences in treatments, obtaining an average value of $32.92 \%$ of ADF in this grass. Already Ribeiro and Pereira (2010) observed increases in the content of ADF with increasing doses of $\mathrm{N}$ and age of regrowth, ranging from $38.0 \%$ to $45.3 \%$ of ADF. Values higher than those of the referring research, with an average value of $28.18 \%$. The fiber content of the food can reduce digestion, consumption of dry mass and limit the energy of the animal, and for the animal to have adequate digestion smaller amounts of fiber are required (Nussio et al., 2010).

\section{Conclusions}

Residual water provided higher values of crude protein, and lower values of neutral detergent fiber and acid detergent fiber when compared to artesian well water.

The higher nitrogen rates from avian litter also influenced positively, increasing the crude protein content in Tifton 85 grass and promoting lower levels of neutral detergent fiber and acid detergent fiber.

\section{References}

Alencar, C. A. B., Cunha, F. F., Martins, C. E., Cóser, A. C., Rocha, W. S. D., \& Araújo, R. A. S. (2009). Irrigação de pastagem: atualidade e recomendações para uso e manejo. Revista Brasileira de Zootecnia, 38, 98-108. https://doi.org/10.1590/S1516-35982009001300012 
Amaral, M. A. C. M. (2014). Desempenho produtivo de Cynodon spp. cv. Tifton 85 sob diferentes condições de manejo da irrigação e momentos de aplicação da adubação nitrogenada (p. 67). Dissertação, Escola Superior de Agricultura "Luiz de Queiroz", Piracicaba, SP, Brasil.

Balsalobre, M. A. A., Corsi, M., Santos, P. M., Vieira, I., \& Cárdenas, R. R. (2003). Composição química e fracionamento do nitrogênio e dos carboidratos do capim-tanzânia irrigado sob três níveis de resíduo pós-pastejo. Revista Brasileira de Zootecnia, 32(3), 519-528. https://doi.org/10.1590/S1516-35982003000 300003

Barbieri Junior, E., Rossiello, R. O. P., Silva, R. V. M. M., Ribeiro, R. C., \& Morenz, M. J. F. (2012). Um novo clorofilômetro para estimar os teores de clorofila em folhas do capim Tifton 85. Ciência rural, Santa Maria, 42(12), 2242-2245. https://doi.org/10.1590/S0103-84782012005000109

Costa, K. A. P., Oliveira, I. P., Faquim, V., Neves, B. P., Rodrigues, C., \& Sampaio, F. M. T. (2007). Intervalo de corte na produção de massa seca e composição químicobromatológica da Brachiaria brizantha cv. MG-5. Ciência e Agrotecnologia, 31(8), 1197-1202. https://doi.org/10.1590/S1413-70542007000400037

EMBRAPA (Empresa Brasileira de Pesquisa Agropecuária). (2014). Centro Nacional de Pesquisa de Solos. Sistema Brasileiro de Classificação de Solos (3rd ed.). Rio de Janeiro: Embrapa Solos.

Fernandes, C., Corá, J. E., \& Araújo, J. A. C. (2004). Utilização do tanque classe A para estimativa da evapotranspiração de referência dentro de casa de vegetação. Engenharia Agrícola, Jaboticabal, 24(1), 46-50. https://doi.org/10.1590/S0100-69162004000100006

Gardner, A. L. (1986). Técnicas de pesquisa em pastagens e aplicabilidade de resultados em sistemas de produção (p. 197). Brasília: IICA/EMBRAPA-CNPGL.

Goering, H. K., \& Van Soest, P. J. (1970). Forage fiber analysis: Apparatus reagents, procedures and some applications. Agricultural Handbook (p. 379). Washington, D. C.

Menegatti, D. P., Rocha, G. P., Furtini Neto, A. E., \& Muniz, J. A. (2002). Nitrogênio na produção de matéria seca, teor e rendimento de proteína bruta de três gramíneas do gênero Cynodon. Ciência agrotecnologia, Lavras, 26(3), 633-642.

Monteiro, D. R., Silva, T. T. S., Silva, L. V. B. D., Lima, V. L. A. de, Santos, C. L. M., \& Pearson, H. W. (2014). Efeito da aplicação de efluente doméstico tratado nos teores de micronutrientes do solo. Irriga, Botucatu, 01, 40-46. https://doi.org/10.15809/irriga.2014v1n1p40

Neres, M. A., Castagnara, D. D., Silva, F. B., Oliveira, P. S. R., Mesquita, E. E., Bernardi, T. C., ... Vogt, A. S. L. (2012). Características produtivas, estruturais e bromatológicas dos capins Tifton 85 e Piatã e do feijão-guandu cv. Super N, em cultivo singular ou em associação. Ciência Rural, Santa Maria, 42(5), 862-869. https://doi.org/10.1590/S0103-84782012000500017

Norton, B. W. (1982). Differences in plant species in forage quality. In: international symposium on nutritional limits to animal production from pasture. Proceedings ... Farnham Royal: Commonwealth Agricultural Bureaux (pp. 89-110). Sta. Lucia.

Nussio, L. G., Campos, F. P., \& Lima, M. L. M. (2010). Metabolismo de carboidratos estruturais. In T. T. Berchielli, A. V. P. Oliveira, \& S. Gisele (Eds.), Nutrição de ruminantes (pp. 193-238). Jaboticabal: Funep.

Poczynek, M., Neumann, M., Horst, Leão, G. F. M., Poczynek, M., \& Ueno, R. K. (2016). Capacidade produtiva e qualidade nutricional de gramíneas perenes submetidas a sistema contínuo de cortes. Arquivo Brasileiro de Medicina Veterinária e Zootecnia, 68(3), 785-794. https://doi.org/10.1590/1678-4162-8768

Quaresma, J. P., Almeida, R. G., Abreu, J. G., Cabral, L. S., Oliveira, M. A., \& Guedes, D. M. (2011). Produção e composição bromatológica do capim-tifton 85 (Cynodon spp) submetido a doses de nitrogênio. Acta Scientiarum. Animal Sciences, Maringá, 33(2), 145-150. https://doi.org/10.4025/actascianimsci.v33i2.9261

Ribeiro, K. G., \& Pereira, O. G. (2010). Valor nutritivo do capim-Tifton 85 sob doses de nitrogênio e idades de rebrotação. Veterinária e Zootecnia, 17(4), 560-567.

Santos, N. L., Silva, M. W. R., \& Chaves, M. A. (2008). Efeito da irrigação suplementar sobre a produção dos capins Tifton 85, Tanzânia e Marandu no período de verão no sudoeste baiano. Ciência Animal Brasiileira (UFG), 09, 911-922.

Silva, A. C. C., Lima, L. A., Almeida, W. F., Tebaldi, M. S., \& Silva, A. C. (2017). Tifton 85 production under déficit irrigation. Revista de La Facultad de Ciencias Agrarias, 49, 1-10. 
Silva, A. F., \& Silva, M. C. B. C. da. (2016). Agricultura no Nordeste Semiárido e os resíduos orgânicos aproveitáveis. Revista Equador (UFPI), 5(2), 102-119.

Silva, E. A., Berchielli, T. T., Reis, R. A., Fernandes, J. J. R., Sato, K. J., \& Paes, J. M. V. (2007). Teores de proteína bruta para bovinos alimentados com feno de tifton 85: consumo e digestibilidades total e parcial. Revista Brasileira de Zootecnia, 36(1), 237-245. https://doi.org/10.1590/S1516-35982007000100028

Silva, F. A. S., \& Azevedo, C. A. V. (2016). The Assistat Software Version 7.7 and its use in the analysis of experimental data. African Journal of Agricultural Research, 11(39), 3733-3740. https://doi.org/10.5897/ AJAR2016.11522

Taffarel, L. E., Mesquita, E. E., Castagnara, D. D., Oliveira, P. S. R., Oliveira, N. T. E., Galbeiro, S., \& Costa, P. B. (2014). Produção de matéria seca e valor nutritivo do feno do tifton 85 adubado com nitrogênio e colhido com 35 dias. Revista Brasileira Saúde e Produção Animal, Salvador, 15(3), 544-560. https://doi.org/ $10.1590 /$ S1519-99402014000300003

Van Soest, P. J., Roberttson, J. B., \& Lewis, B. A. (1991). Methods for dietary fiber, neutral detergent fiber, and nonstarch polysaccharides in relation to animal nutrition, Journal of Dairy Science, Champagne, 74, 3583-3597.

\section{Copyrights}

Copyright for this article is retained by the author(s), with first publication rights granted to the journal.

This is an open-access article distributed under the terms and conditions of the Creative Commons Attribution license (http://creativecommons.org/licenses/by/4.0/). 